\title{
PROBABLE MONTHLY RAINFALL ASSOCIATED WITH DISTINCT BIOMES OF MATO GROSSO DO SUL STATE
}

\author{
PRECIPITAÇÃO MENSAL PROVÁVEL ASSOCIADA AOS DIFERENTES BIOMAS DO \\ ESTADO DE MATO GROSSO DO SUL
}

\author{
Paulo Eduardo TEODORO'; ; Carlos Antonio da SILVA JUNIOR; \\ José Francisco OLIVEIRA-JUNIOR ${ }^{3}$; Rafael Coll DELGADO ${ }^{4}$; Givanildo de GOIS \\ Caio Cezar Guedes CORREA ${ }^{5}$; Francisco Eduardo TORRES ${ }^{6}$ \\ 1. Universidade Federal de Viçosa, Viçosa, MG, Brasil. eduteodoro@hotmail.com; 2. Universidade do Estado de Mato Grosso, Alta Floresta, MT, \\ Brasil; 3. Universidade Federal de Alagoas, Maceió, AL, Brasil; 4. Universidade Federal Rural do Rio de Janeiro, Seropédica, RJ, Brasil; 5. \\ Universidade Estadual do Norte Fluminense, Campos dos Goytacazes, RJ, Brasil; 6. Universidade Estadual de Mato Grosso do Sul, Aquidauana, MS, \\ Brasil.
}

\begin{abstract}
The aim of this study was to determine the probable monthly rainfall for the state of Mato Grosso do Sul, considering the level of $75 \%$ probability, and study the spatial distribution associated with its different biomes. The rainfall data of 32 stations (sites) in the state of Mato Grosso do Sul were collected in the period 1954-2013. In each of the 384 series, the average monthly rainfall was calculated, for at least 30 years of observation. The Kolmogorov-Smirnov adhesion test was applied to the rainfall time series to check the fit of the data to a normal distribution. The likely fallout was estimated at $75 \%$ probability, using the normal probability distribution and, subsequently, it was adopted the method of Ordinary Kriging interpolation mathematics to spatial data. Based on the likely monthly precipitation estimated, the State of Mato Grosso do Sul possess three distinct periods, with the precipitation associated with different biomes: the rainy season (between the months November to March, where increased precipitation occurred in the Savanna biome), dry season (between the months from June to August, when the highest rainfall occurred in the Atlantic Forest) and transition period (April and May and September and October).
\end{abstract}

KEYWORDS: Atlantic Forest. Pantanal. Savanna. Normal distribution.

\section{INTRODUCTION}

Mato Grosso do Sul State (MS) covers an area of approximately $350,000 \mathrm{~km}^{2}$, of which $13,000 \mathrm{~km}^{2}$ are exploited by agriculture, especially soybean, corn, cotton, sugarcane sugar and irrigated rice (CONAB, 2014), which are distributed differently in three biomes of peculiar climatic attributes: Pantanal, Savanna and the Atlantic Forest (TEODORO et al., 2016a,b). Among the main factors that influence crop production, the rainfall and its variation are the most relevant for planning agricultural activities, allowing for better approaches and more reliable decisions (ARAI et al. 2010).

Correa et al. (2014) emphasize that it is possible to plan the best time of tillage, harvest, sowing and fertilizer and defensive application from probable monthly rainfall estimates. Besides the influence in agriculture, very long dry seasons affect the level of water sources and reservoirs of hydroelectric power plants, causing problems to the urban water supply and the electricity generation (RODRIGUES et al. 2013). According to Togashi et al. (2012), Moura et al. (2009) and Arcova et al. (2003) research on this subject is critical for the management of areas subject to flooding, as well for preventing potential problems caused by climate change.

According to Bernardo et al. (2006), probable rainfall can be defined as the minimum amount of precipitation within a given probability of occurrence. Usually, the probability of $75 \%$ is used in irrigation, ie, is the minimum monthly rainfall that should occur in $75 \%$ of the folloing years. These statiscal analyses of rainfall are important for planning of agricultural activities, but also of other activities such as construction, tourism and transport (ULIANA et al. 2013).

Researches investigating the climate in the State of Mato Grosso do Sul are still scarce. There is a variety of meteorological phenomena in this region, from micro-scale to large-scale, which require a better understanding, as for example, soilvegetation-atmosphere interaction processes during dry spells and flood in the Pantanal, which have local and wider climatic effects, especially on rainfall patterns (MESQUITA et al. 2013). Given the above, the aim of this study was to determine the probable monthly rainfall for Mato Grosso do Sul State, considering the level of $75 \%$ probability, and studying the spatial distribution associated with the different biomes of the region.

\section{MATERIAL AND METHODS}

Characterization of the study area

Mato Grosso do Sul State lays in the center of the South American continent and has several 
edaphoclimatic features distributed among three biomes: Savanna, Atlantic Forest and Pantanal. Altitudes vary from 24 to 1,000 $\mathrm{m}$ (TEODORO et al., 2015).

Savanna (or Cerrado) is the second largest biome in South America (SA) and covers 22\% of the Brazilian territory. It is this biome that is the source of three major watersheds of South America (Amazônica/Tocantins, São Francisco and Prata), which results in high aquifer potential and great biodiversity. Due to its latitudinal position, the region is characterized by the transition between the warm low latitude climates and mesothermal type climates of mid-latitudes (NIMER, 1989).

Atlantic Forest is an environmental complex that includes mountain ranges, valleys and plateaus. It was already one of the richest and most varied rainforests of South America, but is currently recognized as the most disturbed and threatened Brazilian biome (Teodoro et al., 2015).

Pantanal covers $25 \%$ of Mato Grosso do Sul State and it is a biome almost exclusive to Brazil. It is characterized by long-term flooding (due to low permeability soil) that occur each year on the plain, and cause changes in the environment, wildlife and local populations daily life. Pantanal climate is Tropical of Savanna (AW), with rainfall totals ranging between 1,000 and $2,000 \mathrm{~mm}$, and two distinct seasons: a dry (May to September) and a rainy (October to April), this latter accounting for more than $80 \%$ of the total annual rainfall (MESQUITA et al. 2013).

\section{Historical Series of Monthly Rainfall}

Rainfall data of 32 stations (sites) of Mato Grosso do Sul (MS) were obtained of the Agência Nacional de Águas (ANA 2014), collected from 1954 to 2013 (Table 1). At each site and year, the rainfall daily data were added up to obtain the monthly rainfall ( $\mathrm{mm}$ monthly ${ }^{-1}$ ), of each month of the year. Thus, they formed 384 time series (12 months $\times 32$ sites), with different numbers of observations years in each series, defined according to the availability of meteorological data.

Table 1. Altitude (m), latitude and longitude $\left(^{\circ}\right.$ ), and observation period of monthly rainfall of 32 municipalities in Mato Grosso do Sul State, Brazil.

\begin{tabular}{|c|c|c|c|c|}
\hline Site & Altitude (m) & Latitude $\left(\mathrm{S},{ }^{\circ}\right)$ & Longitude $\left(\mathrm{W},{ }^{\circ}\right)$ & Period (years) \\
\hline Água Clara & 376 & $20^{\circ} 6^{\prime} 7^{\prime}$ & $52^{\circ} 55^{\prime} 33^{\prime \prime}$ & $1975-2013$ \\
\hline Amambai & 395 & $22^{\circ} 55^{\prime} 59^{\prime}$, & $55^{\circ} 13^{\prime} 0^{\prime \prime}$ & $1973-2013$ \\
\hline Anastácio & 106 & $19^{\circ} 34^{\prime} 0^{\prime \prime}$ & $56^{\circ} 12^{\prime} 0^{\prime}$, & $1960-2000$ \\
\hline Anaurilândia & 284 & $22^{\circ} 11^{\prime} 11^{\prime \prime}$ & $52^{\circ} 42^{\prime} 48^{\prime \prime}$ & $1975-2013$ \\
\hline Aparecida do Taboado & 375 & $20^{\circ} 1^{\prime} 6^{\prime}$ & $51^{\circ} 6{ }^{\prime} 13^{\prime}$ & $1983-2013$ \\
\hline Aquidauana & 155 & $20^{\circ} 27^{\prime} 24^{\prime \prime}$ & $55^{\circ} 40^{\prime} 17^{\prime \prime}$ & $1960-2000$ \\
\hline Bataguassu & 293 & $21^{\circ} 43^{\prime} 33^{\prime \prime}$ & $52^{\circ} 20^{\prime} 3^{\prime}$ & $1975-2013$ \\
\hline Bodoquena & 133 & $19^{\circ} 52^{\prime} 15^{\prime \prime}$ & $56^{\circ} 59^{\prime} 1^{\prime \prime}$ & $1954-2013$ \\
\hline Caarapó & 454 & $22^{\circ} 37^{\prime} 28^{\prime \prime}$ & $54^{\circ} 49^{\prime} 29^{\prime}$, & $1973-2013$ \\
\hline Camapuã & 404 & $19^{\circ} 29^{\prime} 48^{\prime \prime}$ & $53^{\circ} 59^{\prime} 48^{\prime \prime}$ & $1973-2013$ \\
\hline Campo Grande & 559 & $20^{\circ} 28^{\prime} 0^{\prime \prime}$ & $54^{\circ} 40^{\prime} 0^{\prime}$ & $1975-2013$ \\
\hline Chapadão do Sul & 570 & $18^{\circ} 59^{\prime} 52^{\prime \prime}$ & $52^{\circ} 35^{\prime} 17^{\prime \prime}$ & $1983-2013$ \\
\hline Corumbá & 101 & $17^{\circ} 37^{\prime} 24^{\prime \prime}$ & $56^{\circ} 57^{\prime} 54^{\prime \prime}$ & $1983-2013$ \\
\hline Costa Rica & 635 & $18^{\circ} 32^{\prime} 50^{\prime \prime}$ & $53^{\circ} 8^{\prime} 7^{\prime \prime}$ & $1983-2013$ \\
\hline Coxim & 250 & $18^{\circ} 38^{\prime} 57^{\prime \prime}$ & $54^{\circ} 21^{\prime} 26^{\prime \prime}$ & $1973-2013$ \\
\hline Dourados & 293 & $22^{\circ} 23^{\prime} 53^{\prime \prime}$ & $54^{\circ} 47^{\prime} 30^{\prime \prime}$ & $1973-2013$ \\
\hline Glória de Dourados & 422 & $22^{\circ} 24^{\prime} 21^{\prime \prime}$ & $54^{\circ} 14^{\prime} 7^{\prime}$ & $1973-2013$ \\
\hline Iguatemi & 333 & $23^{\circ} 40^{\prime} 55^{\prime \prime}$ & $54^{\circ} 33^{\prime} 42^{\prime \prime}$ & $1975-2013$ \\
\hline Inocência & 502 & $19^{\circ} 44^{\prime} 11^{\prime \prime}$ & $51^{\circ} 56^{\prime} 1^{\prime \prime}$ & $1983-2013$ \\
\hline Maracaju & 356 & $21^{\circ} 37^{\prime} 7^{\prime \prime}$ & $55^{\circ} 8^{\prime} 13^{\prime \prime}$ & $1973-2013$ \\
\hline Miranda & 140 & $20^{\circ} 6^{\prime} 7^{\prime}$ & $56^{\circ} 47^{\prime} 43^{\prime \prime}$ & $1960-2000$ \\
\hline Navirai & 366 & $23^{\circ} 3^{\prime} 28^{\prime \prime}$ & $54^{\circ} 11^{\prime} 38^{\prime \prime}$ & $1975-2013$ \\
\hline Nova Andradina & 271 & $21^{\circ} 36^{\prime} 55^{\prime \prime}$ & $53^{\circ} 3^{\prime} 8^{\prime \prime}$ & $1975-2013$ \\
\hline Paranaíba & 458 & $19^{\circ} 23^{\prime} 27^{\prime \prime}$ & $51^{\circ} 36^{\prime} 32^{\prime \prime}$ & $1983-2013$ \\
\hline Ponta Porã & 650 & $22^{\circ} 32^{\prime} 0^{\prime \prime}$ & $55^{\circ} 43^{\prime} 0^{\prime}$ & $1973-2013$ \\
\hline Porto Murtinho & 83 & $21^{\circ} 42^{\prime} 5^{\prime}$ & $57^{\circ} 53^{\prime} 30^{\prime \prime}$ & $1983-2013$ \\
\hline Ribas do Rio Pardo & 373 & $20^{\circ} 26^{\prime} 41^{\prime \prime}$ & $53^{\circ} 45^{\prime} 29^{\prime \prime}$ & $1975-2013$ \\
\hline Rio Brilhante & 287 & $21^{\circ} 38^{\prime} 50^{\prime \prime}$ & $54^{\circ} 25^{\prime} 31^{\prime \prime}$ & $1973-2013$ \\
\hline Rio Negro & 233 & $19^{\circ} 26^{\prime} 23^{\prime \prime}$ & $54^{\circ} 59^{\prime} 0^{\prime \prime}$ & $1975-2013$ \\
\hline Santa Rita do Pardo & 393 & $21^{\circ} 17^{\prime} 43^{\prime \prime}$ & $52^{\circ} 48^{\prime} 38^{\prime \prime}$ & $1975-2013$ \\
\hline Selviria & 348 & $20^{\circ} 21^{\prime} 49^{\prime \prime}$ & $51^{\circ} 25^{\prime} 26^{\prime \prime}$ & $1983-2013$ \\
\hline Três Lagoas & 313 & $20^{\circ} 47^{\prime} 41^{\prime \prime}$ & $51^{\circ} 42^{\prime} 46^{\prime \prime}$ & $1975-2013$ \\
\hline
\end{tabular}


The processing and the organization of rainfall data of 32 sites in the State were performed. The historical series with failures were eliminated and filled by the climatologically normal from each of the 11 regions of Mato Grosso do Sul State according to the performed by Teodoro et al. (2015).

\section{Estimate of the Probable Rainfall}

In each of the 384 time series of monthly rainfall was calculated the average (m), at least 30 years of observation. The Kolmogorov-Smirnov adhesion test (ASSIS et al., 1996) was applied on 384 monthly rainfall time series to verify their fit to normal distribution.

Probable rainfall was estimated at $75 \%$ probability, using the normal probability distribution according Torres et al. (2016), also named Gaussian curve, which shows two parameters and its probability density function is defined by the equation (HASTINGS; PEACOCK, 1975):

$$
f(x)=\frac{1}{\sigma \sqrt{2 \pi}} e^{\left[-\frac{(x-\mu)^{2}}{2 \sigma^{2}}\right]}
$$

where: $\mu$ is the average and $\sigma$ the standard deviation.

Statistical analyzes were performed with the software Genes (CRUZ, 2013) and Microsoft Office Excel $^{\circledR}$.

\section{Geographical Distribution of the Probable Rainfall}

In this study was adopted the ordinary kriging mathematical interpolation method (OK) which allows to calculate local averages, limiting the average stationary domain to local neighborhood centered on the point to be estimated. Values of $z$ dimension are estimated at spatial locations $\left(\mathrm{x}_{\mathrm{j}}, \mathrm{y}_{\mathrm{j}}\right)$ unobserved, without the need to know the stationary average, from a linear combination of the values of a local sampling subset. The condition set out in this study was the sum of the weights of OK $\lambda_{\mathrm{i}}\left(\mathrm{x}_{\mathrm{j}}, \mathrm{y}_{\mathrm{j}}\right)$ to be equal to 1 (Equation 2).

$$
\mathrm{Z}\left(\mathrm{x}_{\mathrm{j}}, \mathrm{y}_{\mathrm{j}}\right)=\sum_{\mathrm{i}=1}^{\mathrm{n}(\mathrm{j})} \lambda_{\mathrm{i}}\left(\mathrm{x}_{\mathrm{j}}, \mathrm{y}_{\mathrm{j}}\right) \times \mathrm{Z}\left(\mathrm{x}_{\mathrm{i}}, \mathrm{y}_{\mathrm{i}}\right),
$$

where:

$$
\mathrm{Z}\left(\mathrm{x}_{\mathrm{j}}, \mathrm{y}_{\mathrm{j}}\right) \text { is the value estimated by kriging }
$$
in the point $\left(\mathrm{x}_{\mathrm{j}}, \mathrm{y}_{\mathrm{j}}\right) ; \mathrm{Z}\left(\mathrm{x}_{\mathrm{i}}, \mathrm{y}_{\mathrm{i}}\right)$ is the value of the sample in the point $\left(\mathrm{x}_{\mathrm{i}}, \mathrm{y}_{\mathrm{i}}\right) ; \lambda_{\mathrm{i}}\left(\mathrm{x}_{\mathrm{j}}, \mathrm{y}_{\mathrm{j}}\right)$ is the weight of the OK to the specified location.

It was utilized the circular theoretical mathematical model, as recommended by Correa et al. (2014). The spatial distribution of the probable monthly rainfall data was analyzed with the assistance of geostatistical software ArcGis $10.1^{\circledR}$.

\section{RESULTS AND DISCUSSION}

Kolmogorov-Smirnov test revealed that the data of 359 monthly rainfall time series (93.49\%) fit to normal distribution $(\mathrm{P}>0.01)$ (Table 2). Given these high percentages with fit to normal distribution, it can be concluded that the use of normal distribution has credibility for estimating the monthly rainfall in the Mato Grosso do Sul State, agreeing with the results obtained by Torres et al. (2016).

\begin{tabular}{|c|c|c|c|c|c|c|c|c|c|c|c|c|}
\hline City & JAN & FEB & MAR & APR & MAY & JUN & JUL & AUG & SEP & OCT & NOV & DEC \\
\hline Água Clara & $\mathrm{S}$ & $\mathrm{S}$ & $\mathrm{S}$ & $\mathrm{S}$ & $\mathrm{S}$ & $\mathrm{S}$ & $\mathrm{N}$ & $\mathrm{N}$ & $\mathrm{S}$ & $\mathrm{S}$ & $\mathrm{S}$ & $\mathrm{S}$ \\
\hline Amambai & $S$ & $S$ & S & S & $S$ & $S$ & S & S & S & S & $\mathrm{S}$ & $S$ \\
\hline Anastácio & $S$ & $\mathrm{~S}$ & $S$ & S & $S$ & $S$ & $S$ & $\mathrm{~S}$ & $S$ & $S$ & $\mathrm{~S}$ & $S$ \\
\hline Anaurilândia & $S$ & S & S & S & S & $S$ & S & S & S & S & S & S \\
\hline Aparecida do Taboado & S & S & S & S & S & $\mathrm{N}$ & S & S & S & S & $\mathrm{S}$ & S \\
\hline Aquidauana & $\mathrm{S}$ & S & S & S & S & S & S & $\mathrm{S}$ & S & $\mathrm{S}$ & $\mathrm{S}$ & S \\
\hline Bataguassu & $\mathrm{S}$ & S & S & S & S & $\mathrm{S}$ & S & $\mathrm{S}$ & S & $\mathrm{S}$ & $\mathrm{S}$ & S \\
\hline Bodoquena & S & S & $\mathrm{N}$ & S & S & $\mathrm{N}$ & S & $\mathrm{N}$ & S & S & S & S \\
\hline Caarapó & $\mathrm{S}$ & $S$ & S & S & S & S & S & S & S & $\mathrm{S}$ & S & S \\
\hline Camapuã & $S$ & S & S & S & $S$ & $S$ & S & $\mathrm{N}$ & S & S & S & S \\
\hline Campo Grande & $S$ & S & $S$ & S & $S$ & $\mathrm{~S}$ & $S$ & $S$ & $S$ & $S$ & S & $S$ \\
\hline Chapadão do Sul & S & S & S & S & S & $S$ & S & S & S & S & S & $S$ \\
\hline Corumbá & S & S & S & S & S & S & S & S & S & $\mathrm{S}$ & S & S \\
\hline Costa Rica & S & S & S & S & S & $\mathrm{S}$ & S & $\mathrm{S}$ & S & S & $\mathrm{S}$ & S \\
\hline Coxim & S & S & S & $S$ & $S$ & S & $S$ & $S$ & $S$ & $S$ & $\mathrm{~S}$ & S \\
\hline Dourados & $\mathrm{S}$ & $\mathrm{S}$ & $S$ & S & S & $\mathrm{S}$ & S & $\mathrm{N}$ & $\mathrm{N}$ & $\mathrm{S}$ & $S$ & S \\
\hline Glória de Dourados & S & S & S & S & S & S & S & S & $S$ & $S$ & S & S \\
\hline Iguatemi & S & S & S & S & S & $\mathrm{S}$ & S & $\mathrm{S}$ & S & $\mathrm{S}$ & $\mathrm{S}$ & S \\
\hline Inocência & S & $S$ & S & S & S & $S$ & S & S & $S$ & $\mathrm{~S}$ & $S$ & S \\
\hline
\end{tabular}

Table 2. Normality tests (Kolmogorov-Smirnov, KS) regarding to 384 monthly rainfall time series in sites of Mato Grosso do Sul State. 
Probable monthly...

TEODORO, P. E. et al.

\begin{tabular}{|c|c|c|c|c|c|c|c|c|c|c|c|c|}
\hline Maracaju & $S$ & S & $\mathrm{S}$ & $S$ & $S$ & $S$ & $\mathrm{~S}$ & $\mathrm{~S}$ & $\mathrm{~S}$ & $\mathrm{~S}$ & $S$ & $\mathrm{~S}$ \\
\hline Miranda & $\mathrm{N}$ & $\mathrm{N}$ & $\mathrm{N}$ & $\mathrm{N}$ & $\mathrm{N}$ & $\mathrm{N}$ & $\mathrm{N}$ & $\mathrm{N}$ & $\mathrm{N}$ & $\mathrm{N}$ & $\mathrm{N}$ & $\mathrm{N}$ \\
\hline Navirai & $S$ & S & $\mathrm{S}$ & S & $\mathrm{S}$ & $\mathrm{S}$ & $\mathrm{S}$ & S & $\mathrm{S}$ & $\mathrm{S}$ & S & $\mathrm{S}$ \\
\hline Nova Andradina & S & S & $\mathrm{S}$ & S & S & $S$ & $S$ & $\mathrm{~S}$ & S & S & S & $\mathrm{S}$ \\
\hline Paranaíba & $S$ & S & $S$ & $S$ & $S$ & $S$ & $S$ & $\mathrm{~S}$ & $S$ & S & $S$ & $S$ \\
\hline Ponta Porã & $S$ & $\mathrm{~N}$ & $S$ & $S$ & $\mathrm{~N}$ & $S$ & $S$ & $\mathrm{~S}$ & S & S & $\mathrm{N}$ & $\mathrm{S}$ \\
\hline Porto Murtinho & S & S & $S$ & S & $\mathrm{S}$ & S & S & S & S & S & S & $\mathrm{S}$ \\
\hline Ribas do Rio Pardo & S & S & $\mathrm{S}$ & S & $S$ & $S$ & S & $\mathrm{S}$ & $S$ & S & S & $S$ \\
\hline Rio Brilhante & $S$ & $\mathrm{~S}$ & $\mathrm{~S}$ & $S$ & $S$ & $S$ & $S$ & $\mathrm{~S}$ & $S$ & S & $S$ & $S$ \\
\hline Rio Negro & S & $\mathrm{S}$ & $\mathrm{S}$ & $S$ & $S$ & $S$ & $\mathrm{~S}$ & $\mathrm{~S}$ & S & $S$ & $\mathrm{~S}$ & $\mathrm{~S}$ \\
\hline Santa Rita do Pardo & $S$ & $\mathrm{~S}$ & $\mathrm{~S}$ & $S$ & $S$ & $\mathrm{~S}$ & $S$ & $\mathrm{~S}$ & $S$ & S & $S$ & $\mathrm{~S}$ \\
\hline Selviria & S & S & $\mathrm{S}$ & S & S & $\mathrm{N}$ & S & $\mathrm{S}$ & S & S & S & $\mathrm{S}$ \\
\hline Três Lagoas & S & $S$ & $\mathrm{~S}$ & $S$ & $\mathrm{~S}$ & $\mathrm{~S}$ & $S$ & $\mathrm{~S}$ & $\mathrm{~S}$ & $\mathrm{~S}$ & S & $S$ \\
\hline
\end{tabular}

$\mathrm{S}=$ Normal distribution, by Kolmogorov-Smirnov test $(\mathrm{P}>0.01)$. $\mathrm{N}=$ non-normal $(\mathrm{P} \leq 0.01)$.

The greatest probable precipitation values at $75 \%$ probability by normal distribution occurred between the months of November to April, which allows us to classify these months as the rainiest months of the year in Mato Grosso do Sul (Figure 1).

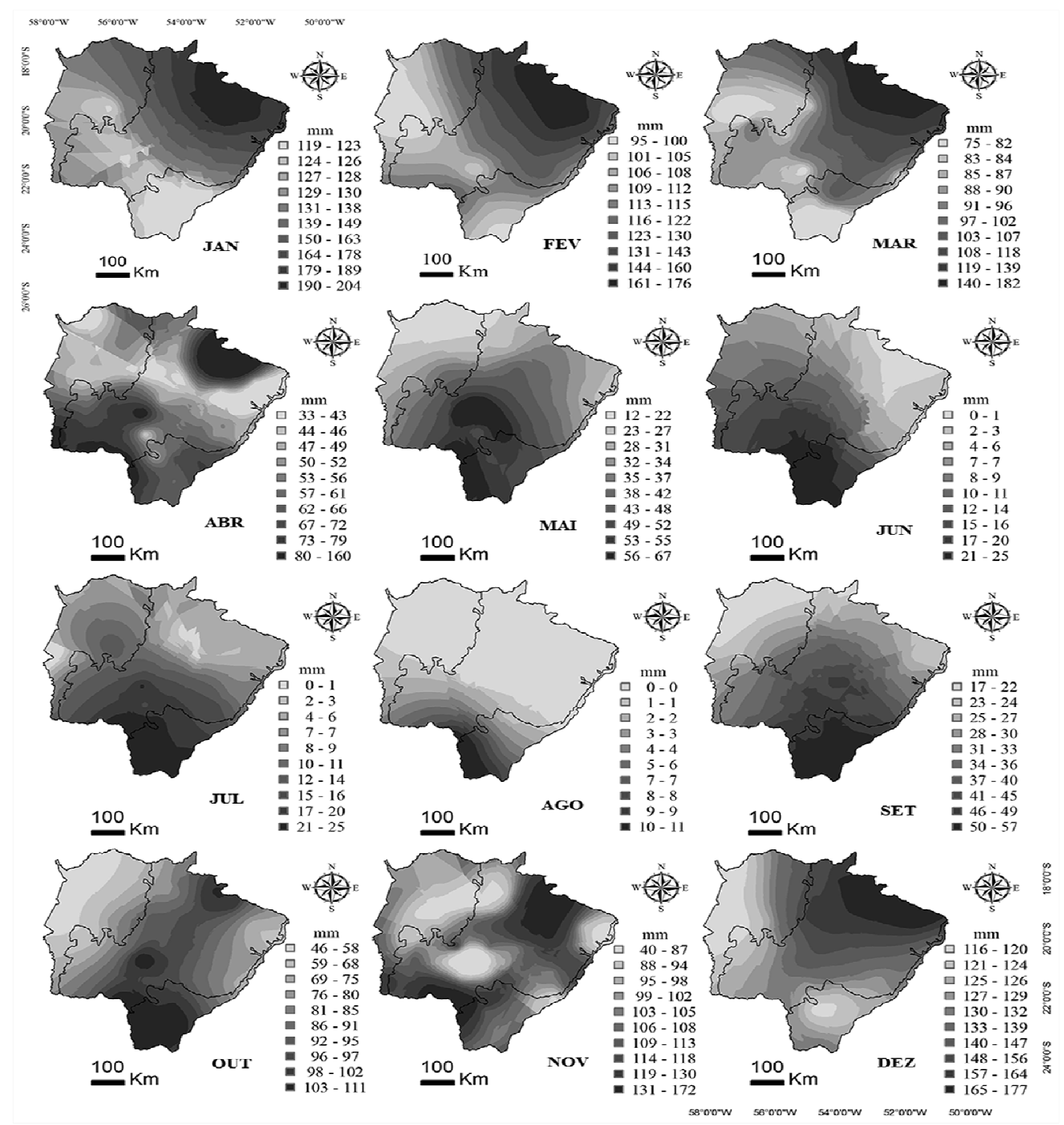

Figure 1. Probable rainfall for Mato Grosso do Sul State from January to December, estimated by normal distribution at $75 \%$ probability of occurrence. 
The lowest probable precipitation values at $75 \%$ probability by normal distribution occurred between the months of June, July and August, demonstrating that this is the driest period of the year in the Mato Grosso do Sul State. In addition to this, April, May, September and October showed intermediary probable monthly rainfall, being characterized as transitional periods between the rainy and the dry season of the year.

Moreover, we verified that the municipalities located in the Savanna biome had the highest values. This region is under the influence of the South Atlantic Subtropical Anticyclone and the Polar migratory, Chaco's Low and Bolivia's High, which operate in the summer and spring and influence the weather conditions in the Midwest region. Another weather system that determines the rainfall pattern in the whole region is the South Atlantic Convergence Zone, favored by Low Level Jet, its draining comes from the channeling of the trade winds that enter the South American continent, carrying water vapor from the Equatorial Atlantic and the Amazon basin towards the southwest Atlantic (CARVALHO et al. 2004; KELLER FILHO et al., 2005).

The municipalities located in the Atlantic Forest had higher probable rainfall at $75 \%$ probability by the normal distribution during the months of May to October. The Upper Level Low, acts from a subtropical origin, that causes rain and strong winds in this region (CASTRO et al., 1994) and finally the passage of Frontal Systems. The complex action of these weather systems explains the highest average monthly rainfall in dry seasons (KELLER FILHO et al., 2005).

The municipalities located in Pantanal showed intermediate probable rainfall during most of the year, except for the months of August,
September and October, which showed lower estimates at $75 \%$ probability of occurrence. In this biome, the main weather systems responsible for rainfall are the passages of Frontal Systems and heated branches, which hold $67 \%$ of the rainfall origins, followed by the South Atlantic Convergence Zone and Upper Level Low from the subtropical origin (KELLER FILHO et al., 2005).

The topographic aligning, arranged in the longitudinal direction (NE-SW) shows morphological features clearly defined: the plain and the plateau. This behavior shows that despite the tropical features present in Mato Grosso do Sul, the altitude is among the physiographic factors, followed by the latitude, the most factor influential in the monthly rainfall during dry, transitional, and rainy seasons, regardless of the period of the year, resembling the results obtained in studies performed in other Brazilian States (BAÚ et al., 2006; ÁVILA et al., 2009; ULIANA et al., 2013).

\section{CONCLUSIONS}

The State of Mato Grosso do Sul possess three distinct rainfall periods, associated with different biomes: the rainy season (between the months November to March, where increased precipitation occur in the Savanna biome), dry season (between the months from June to August, when the highest rainfall occurring in the Atlantic Forest) and transition period (April and May and September and October).

\section{ACKNOWLEDGEMENTS}

To Agência Nacional de Águas (ANA) for data provision for present study.

RESUMO: O objetivo estudo foi determinar a precipitação mensal provável para o Estado de Mato Grosso do Sul, considerando o nível de $75 \%$ probabilidade e estudar sua distribuição espacial associada aos seus diferentes biomas. Os dados de precipitação pluvial de 32 estações (locais) do Estado do Mato Grosso do Sul foram coletados do período de 1954 a 2013 . Em cada uma das 384 séries temporais de precipitação pluvial mensal calculou-se a média, com no mínimo 30 anos de observação. Foi aplicado o teste de aderência de Kolmogorov-Smirnov nas 364 séries temporais de precipitação pluvial mensal para verificar o ajuste dos dados a distribuição normal. A precipitação provável foi estimada a $75 \%$ de probabilidade, utilizando-se a distribuição de probabilidade normal e, posteriormente, foi adotado o método de interpolação matemática da Krigagem Ordinária para espacialização dos dados. Com base na precipitação mensal provável, estimada pela distribuição normal a 75\% de probabilidade, o Estado do Mato Grosso do Sul possuí três períodos distintos, estando à precipitação associada aos diferentes biomas: período chuvoso (entre os meses de novembro a março, onde as maiores precipitações ocorrem no bioma Cerrado), período seco (entre os meses de junho a agosto, onde as maiores precipitações ocorrem no bioma Mata Atlântica) e período de transição (meses de abril e maio e setembro e outubro).

PALAVRAS-CHAVE: Série temporal Erro de estimação. Tamanho de amostra. Amostragem. 


\section{REFERENCES}

ARAI, F. K.; GONÇALVES, G. G. G.; PEREIRA, S. B.; COMUNELLO, E.; VITORINO, A. C. T.; DANIEL, O. Espacialização da precipitação e erosividade na Bacia Hidrográfica do Rio Dourados - MS. Engenharia Agrícola, Jaboticabal, v. 30, n. 5, p. 922-931, 2010.

ARCOVA, F. C. S.; CICCO, V.; ROCHA, P. A. B. Precipitação efetiva e interceptação das chuvas por floresta de mata atlântica em uma microbacia experimental em Cunha - São Paulo. Revista Árvore, Viçosa, v. 27, n. 2, p. 257-262, 2003.

ASSIS, F. N.; ARRUDA, H. V.; PEREIRA, A. R. Aplicações de estatística a climatologia: teoria e prática. Pelotas: Universitária, 1996. 161p.

ÁVILA, L. F.; MELLO, C. R.; VIOLA, M. R. Mapeamento da precipitação mínima provável para o sul de Minas Gerais. Revista Brasileira de Engenharia Agrícola e Ambiental, Campina Grande, v. 13, p. 906-915, 2009. https://doi.org/10.1590/S1415-43662009000700013

BAÚ, A. L.; GOMES, B. M.; QUEIROZ, M. M. F.; OPAZO, M. A. U.; SAMPAIO, S. C. Comportamento espacial da precipitação pluvial mensal provável da mesoregião oeste do Estado do Paraná. Irriga, Botucatu, v. 11, p. 150-168, 2006.

BERNARDO, S.; SOARES, A. A.; MANTOVANI, E. C. Manual de Irrigação. 8. ed. Viçosa: UFV, 2006. 625 p.

CARVALHO, L. M. V.; JONES, C.; LIEBMANN, B. The South Atlantic Convergence Zone: persistence, intensity, form, extreme precipitation and relationships with intraseasonal activity. Journal of Climate, Boston, v. 17, p. 88-108, 2004. https://doi.org/10.1175/1520-0442(2004)017<0088:TSACZI>2.0.CO;2

CONAB: Companhia Nacional de Abastecimento. Acompanhamento de safra brasileira: grãos, décimo levantamento, julho 2014.

CORREA, C. C. G.; TEODORO, P. E.; CUNHA, E. R.; OLIVEIRA-JÚNIOR, J. F.; GÓIS, G.; RIBEIRO, L. P.; BACANI, V. M.; TORRES, F. E. Spatial interpolation of annual rainfall in the State Mato Grosso do Sul (Brazil) Using Different Transitive Theoretical Mathematical Models. International Journal of Innovative Research in Science, Engineering and Technology, Tamilnadu, v. 3, n. 10, p. 16618-16625, 2014.

CASTRO, L. H. R.; MOREIRA, A. M.; ASSAD, E. D. Definição e regionalização dos padrões pluviométricos dos cerrados brasileiros. In: ASSAD, E. D. Chuvas nos cerrados: análise e espacialização. Brasília, EmbrapaCPAC/Embrapa-SPI, 1994. 423p.

CRUZ, C. D. GENES - a software package for analysis in experimental statistics and quantitative genetics. Acta Scientiarum Agronomy, Maringá, v. 35, p. 271-276, 2013.

HASTINGS, N. A. J.; PEACOCK, J. B. Statistical distributions: a handbook for students and practitioners. New York: J. Wiley, 1975. 130p.

KELLER FILHO, T.; ASSAD, E. D.; LIMA, P. R. S. R. Regiões pluviometricamente homogêneas no Brasil. Pesquisa Agropecuária Brasileira, Brasília, v. 40, n. 3, p. 311-322, 2005 https://doi.org/10.1590/s0100-204x2005000400001

MESQUITA, F. L. L.; MARQUES FILHO, E. P.; KARAM, H. A.; ÁLVALA, R. C. S. Balanço de radiação no Pantanal Sul-Mato-Grossense durante a estação seca. Revista Brasileira de Meteorologia, São José dos Campos, v. 28., n1, p. 65-74, 2013.

MOURA, A. E. S.; CORREA, M. M.; SILVA, E. R.; FERREIRA, R. L. C.; FIGUEIREDO, A. C.; POSSAS, M. C. Interceptação das chuvas em um fragmento de floresta da mata atlântica na Bacia do Prata, Recife, PE. Revista Árvore, Viçosa, v. 33, n. 3, p.461-469, 2009. 
NIMER, E. Climatologia do Brasil. 2.ed. Rio de Janeiro: Fundação IBGE, 1989. 421p.

RODRIGUES, J. A.; SANTOS FILHO, J.; CHAVES, L. M. Funções densidade de probabilidade para a estimativa da precipitação mensal. Semina: Ciências Exatas e Tecnológicas, Londrina, v. 34, p. 03-08, 2013.

TEODORO, P. E.; CARGNELUTTI FILHO, A.; TORRES, F. E.; RIBEIRO, L. P.; CARPISTO, D. P.; CORRÊA, C. C. G.; CUNHA, E. R.; BACANI, V. M. Functions of probability for fitting monthly rainfall in sites of Mato Grosso do Sul state. Bioscience Journal (Online), Uberlândia, v. 32, p. 319-327, 2016a. http://dx.doi.org/10.14393/BJv32n2a2016-29394 https://doi.org/10.14393/BJ-v32n2a2016-29394

TEODORO, P. E.; CUNHA, E. R.; CORREA, C. C. G. ; RIBEIRO, L. P.; TORRES, F. E.; OLIVEIRA-JUNIOR, J. F.; GOIS, G.; BACANI, V. M. Altitude and geographic coordinates to estimate monthly rainfall in the state of Mato Grosso do Sul. Bioscience Journal (Online), Uberlândia, v. 32, p. 41-47, 2016b. http://dx.doi.org/10.14393/bj-v32n1a201629387 https://doi.org/10.14393/BJ-v32n1a2016-29387

TEODORO, P. E.; OLIVEIRA-JUNIOR, J. F.; CUNHA, E. R.; CORREA, C. C. G.; TORRES, F. E.; BACANI, V. M.; GOIS, G.; RIBEIRO, L. P. Cluster analysis applied to the spatial and temporal variability of monthly rainfall in Mato Grosso do Sul State, Brazil. Meteorology and Atmospheric Physics, Vienna, v. 126, p. 1-13, 2015. http://dx.doi.org/10.1007/s00703-015-0408-y

TOGASHI, H. F.; MONTEZUMA, R. C. M.; LEITE, A. F. Precipitação incidente e fluxo de atravessamento das chuvas em três estágios sucessionais de floresta atlântica no Maciço da Pedra Branca, Rio de Janeiro. Revista Árvore, Viçosa, v. 36, n. 5, p. 907-917, 2012.

TORRES, F. E.; CARGNELUTTI FILHO, A.; TEODORO, P. E.; CORREA, C. C. G.; RIBEIRO, L. P.; CUNHA, E. R. Dimensionamento amostral para a estimação da média de precipitação pluvial mensal em locais do Estado do Mato Grosso do Sul. Ciência Rural, Santa Maria, v. 46, p. 60-69, 2016. http://dx.doi.org/10.1590/0103-8478cr20150348 https://doi.org/10.1007/s00703-015-0408-y

ULIANA, T. M.; REIS, E. F.; SILVA, J. G. F.; XAVIER, A. C. Precipitação mensal e anual provável para o Estado do Espírito Santo. Irriga, Botucatu, v. 1 8, p. 139-147, 2013. 